\title{
PROBLEMS FACING CONSTRUCTION PROJECT CONSULTANT IMPLEMENTATION IN SAUDI ARABIA
}

\author{
Abdeliazim Mustafa Mohamed ${ }^{1}$, Mohamed Abdelshafea Abdelrahman ${ }^{2}$, Mahmoud Moustafa ${ }^{3}$ \\ ${ }^{1,2}$ Civil Engineering Department, Alzaem Alazhari University (AAU), Sudan \\ ${ }^{1,3}$ Civil Engineering Department, Prince Sattam Bin Abdulaziz University (PSAU), Saudi Arabia \\ a.bilal@psau.edu.sa
}

\begin{abstract}
Construction engineering projects in Saudi Arabia suffering to meet construction project objectives. Several problems are recently raised in Saudi construction projects such as conflicts between project parties, projects cost overrun, and delay in delivering the projects. The aim of this study is to determine and evaluate the problems facing construction projects consultant implementation and their relative importance to the project parties. A survey questionnaire was carried out for the governmental and private sectors working in the field of construction projects in Saudi Arabia. The results were analyzed with different statistical tools using SPSS Statistical Package for Social Sciences. It was found that the main problem facing construction projects consultant implementation is unqualified and contractor experience which represents $68 \%$ of the factors controlling construction projects.
\end{abstract}

Keywords: Construction Project, Consultant, Problems, Implementation, Saudi Arabia.

\section{INTRODUCTION}

The construction industry in Saudi Arabia has a growth rate of 30 to 40 percent of the total country economy [1]. According to the statistical, the government sector spent around \$234 billion in the infrastructure projects from 1990 to 2000 [2]. Saudi construction industry facing real challenges of maintaining the huge construction project problems such as cost overrun and delay in completion time $[3,4]$. That's why the performance of consultant services requires improvement to meet construction project objectives. Project consultant services defined as a process of study, analysis the structure, identifies the problems, creating strategies and finding opportunities to solve the problems in order to achieve the client satisfaction and project goals.

This study intended to determine and evaluate the problem faced construction industry implementation in Saudi Arabia in order to overcome the problems of delay, cost overrun and provide better quality.

\section{RESEARCH METHOD}

This part of the study described the questionnaire design, data collection and data analysis method. Numbers of problems facing construction field were collected from engineering consultation directory in Saudi Arabia. A set of questionnaires were developed and carried out for the governmental and private construction sectors to evaluate the problems faced the implementation of construction project consultant in Saudi construction industry. In addition to, determine the level of importance of the particular problems. Data were collected from the Engineering Consultation Directory in Saudi Arabia [5]. Collected data from the survey were analyzed using SPSS statistical package version 10.6. [6]. Total numbers of distributed questionnaires is 50 sets. The cumulative rate of return is 68 percent which is 34 sets. 20 percent were returned from the private sector and 14 percent were collected from the public sector companies.

\subsection{Questionnaire Design}

Set of questionnaire survey was drafted, to determine the problems that are facing the implementation of construction project consultant in Saudi Arabia construction industry. Each draft were divided into two main parts, the first part is general information about the company. The second part present list of problems that are labeled and categorized to five scales, respondent were requested to answer survey questions according to their practical experience in the construction field, about the problems that were faced the implementation the project consultant in the construction industry.

\subsection{Data Analysis}

All collected data from the survey were analyzed using SPSS software, which is divided into two methods. The first method is preliminary analysis of frequency presented in form of tables. This method shows the frequency and percentage of data. The second method is average index which is used to determine the values' strength using the following formula [7].

Where,

$$
\text { Average Index }=\frac{\sum a i x i}{\sum x i}
$$

$a i=$ constant weight given to $i$.

$x i=$ frequency of the response for $\mathrm{i}$.

$\mathrm{i}=1,2,3,4,5$

Label scale is used for answering technique which is divided into five scale rating categories reported by [8] are described in table 1 below 
Table 1: Rating scale categories

\begin{tabular}{|l|l|l|}
\hline Rating & Scale & Classification \\
\hline 1 & $\begin{array}{l}\text { Substantially } \\
\text { disagree }\end{array}$ & $5.00<$ Average Index $<4.50$ \\
\hline 2 & Disagree & $3.50<$ Average Index $<4.50$ \\
\hline 3 & Not sure & $2.50<$ Average Index $<3.50$ \\
\hline 4 & Agree & $1.50<$ Average Index $<2.50$ \\
\hline 5 & $\begin{array}{l}\text { Substantially } \\
\text { agree }\end{array}$ & $1.50<$ Average Index $<1.00$ \\
\hline
\end{tabular}

\section{RESULTS}

This section discusses the importance of the problems facing consultant in the construction industry in Saudi Arabia. Table 2 represents a summary of the survey carried out for the problems faced project consultant implementation in Saudi construction, frequency and percent of respondent, average index and standard divisions. The results will be presented more in details in the following section.

Table 2: Problems faced project consultant implementation in the project

\begin{tabular}{|c|c|c|c|c|c|c|c|c|c|c|c|c|c|}
\hline No & Description & $\mathbf{1}$ & $\mathbf{\%}$ & $\mathbf{2}$ & $\mathbf{\%}$ & $\mathbf{3}$ & $\mathbf{\%}$ & $\mathbf{4}$ & $\mathbf{\%}$ & $\mathbf{5}$ & $\mathbf{\%}$ & $\begin{array}{c}\text { Average } \\
\text { Index }\end{array}$ & $\begin{array}{c}\text { Std. } \\
\text { Deviation }\end{array}$ \\
\hline 1 & Unclear statement by client. & 0 & 0 & 2 & 6 & 6 & 17 & 16 & 47 & 10 & 30 & 4.00 & 0.85 \\
\hline 2 & $\begin{array}{c}\text { Lake of ability to manage and } \\
\text { schedule }\end{array}$ & 0 & 0 & 5 & 15 & 6 & 18 & 14 & 41 & 9 & 26 & 3.79 & 0.68 \\
\hline 3 & Problem of many projects. & 16 & 47 & 13 & 38 & 5 & 15 & 0 & 0 & 0 & 0 & 1.67 & 0.63 \\
\hline 4 & $\begin{array}{c}\text { Poor coordination between } \\
\text { project parties. }\end{array}$ & 7 & 20 & 18 & 53 & 4 & 12 & 5 & 15 & 0 & 0 & 2.20 & 0.98 \\
\hline 5 & $\begin{array}{c}\text { Lack of commitment between } \\
\text { the parties. }\end{array}$ & 0 & 0 & 4 & 12 & 2 & 6 & 16 & 47 & 12 & 35 & 4.05 & 0.87 \\
\hline 6 & $\begin{array}{c}\text { Unqualified and experience } \\
\text { contractor }\end{array}$ & 9 & 26 & 23 & 68 & 2 & 6 & 0 & 0 & 0 & 0 & 1.79 & 0.76 \\
\hline 7 & Shortage of manpower & 0 & 0 & 0 & 0 & 2 & 6 & 17 & 50 & 15 & 44 & 4.38 & 0.65 \\
\hline
\end{tabular}

\subsection{Unclear Client Statement}

The number of respondents who "disagree" with unclear client statement in Saudi Arabia construction industry, have the highest percent $47 \%$, for the respondents strongly disagree represents $30 \%, 17 \%$ for the respondent who are not sure in their decisions, and 6\% respondents who are agreed with unclear client statement the result are presented in figure 1. The value of an average index is 4.00 and the standard deviation is 0.85 shown in table 2 . It can be noted that the unclear client statement it's not one of the problems that are faced project consultant implementation in Saudi Arabia construction industry.

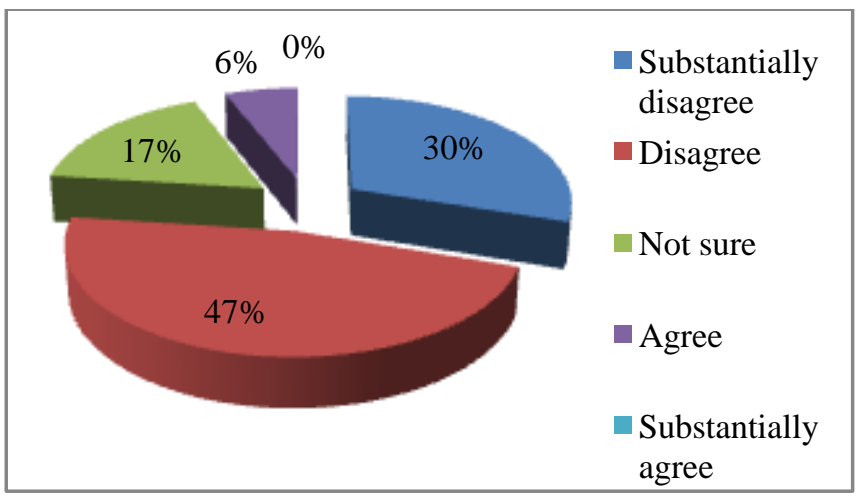

Figure 1: Percentages of respondents for "unclear client statement".

\subsection{Lake Of Ability To Manage The Schedule Of}

\section{The Project}

The respondents that "disagree" with the lake of ability to manage the schedule in Saudi construction industry, has the highest percentage $41 \%$. 26\% respondents were substantially disagreed, the respondents who are not sure in their decision represents $18 \%$ while the respondents who are agreed with lack of ability to manage the schedule in Saudi construction industry is $15 \%$. Fig. 2 the average index score estimated to be 3.79 and standard deviation is 0.68 tables 2 . From statics it is clear that the lack of ability to manage the schedule is not one of the problem faced the project consultant implementation in Saudi Arabia construction industry

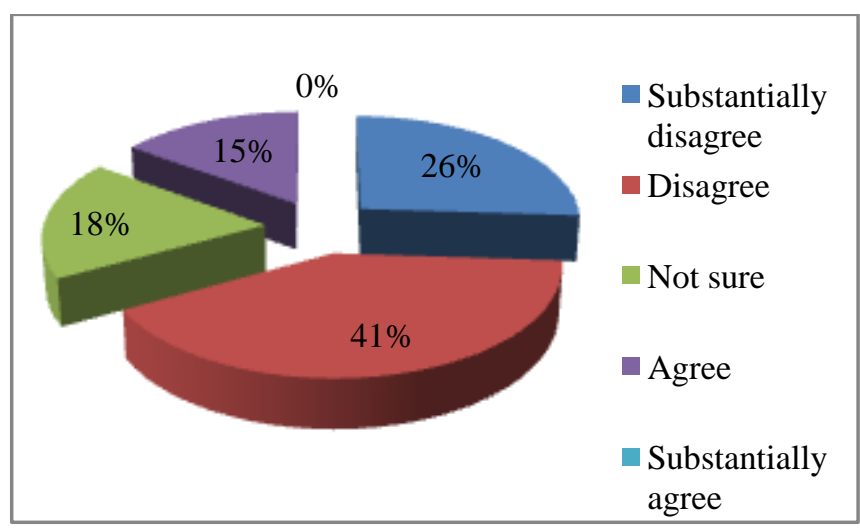

Figure 2: Percentages of respondents for "Lake of ability to manage the schedule".

\subsection{Problem Of Many Project In Hand.}

Respondents are "substantially agree" with that the problem of many projects in Saudi construction industry, has the highest percent $47 \%$, while $38 \%$ of the respondents are "agree" in their decision, the respondent who are not sure represents $15 \%$ fig. 3 . The average index value and standard 
deviation are estimated to be 1.67 and 0.63 respectively table 2. It is clear that, the problem of many projects in hand is one of the problems faced project consultant implementation in Saudi Arabia construction industry.

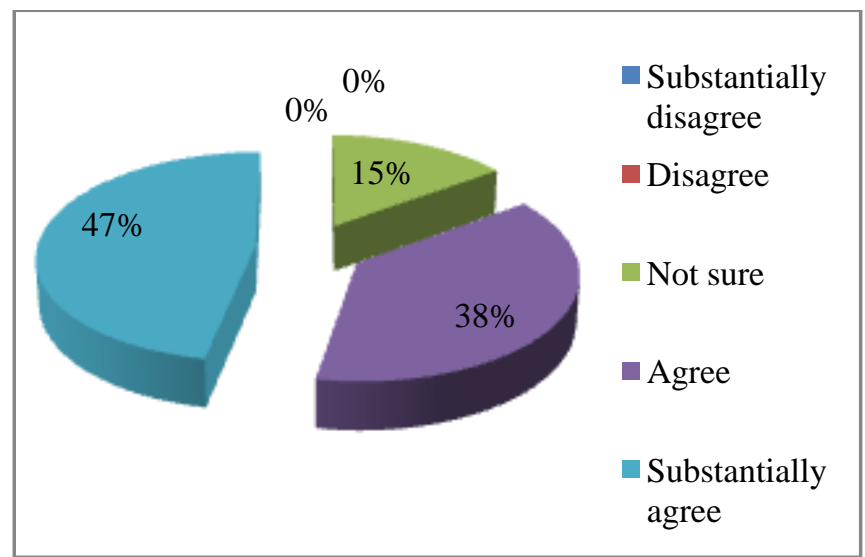

Figure 3: Percentages of respondents for "Problem of many projects in hand".

\subsection{Poor Coordination Between Project Parties}

From figure 4 it is clear that the respondent's percentage "agree" with that the poor coordination's between projects parties in Saudi construction industry is the highest percent $53 \%$. Respondents that "substantially disagree" represent $20 \%$, and the respondents that are not sure in their decision scores $15 \%$. Finally, the respondents "disagree" with poor coordination between project parties' score $12 \%$ fig. 4 . The average index value and standard deviation is 0.98 and 2.20 respectively table 2 . It is clear that the poor coordination between project parties is one of the problems faced project consultant implementation in Saudi Arabia construction industry.

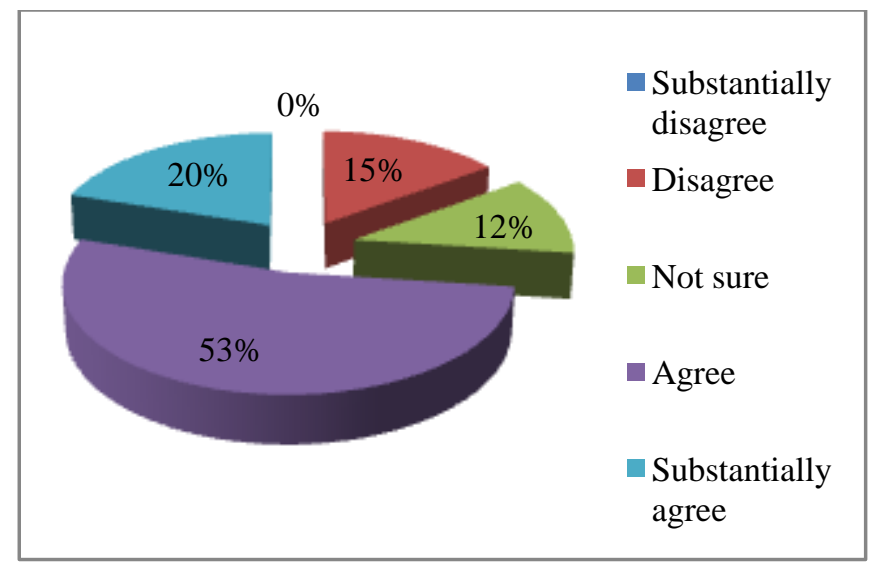

Figure 4: Percentages for "poor coordination between project parties"

\subsection{Lack of commitment between the parties}

The respondent's percentages that "disagree", "substantially disagree", "agree" and not sure with problem of lack commitment between parties in Saudi construction industry are $47 \%, 35 \%, 12 \%$ and $6 \%$ respectively fig.5. The calculated average index and the standard deviation values 4.05 and 0.87 respectively table 2 . It can be concluded that the problem of lack of commitment between project parties is not a problem faced the project consultant in Saudi Arabia construction industry.

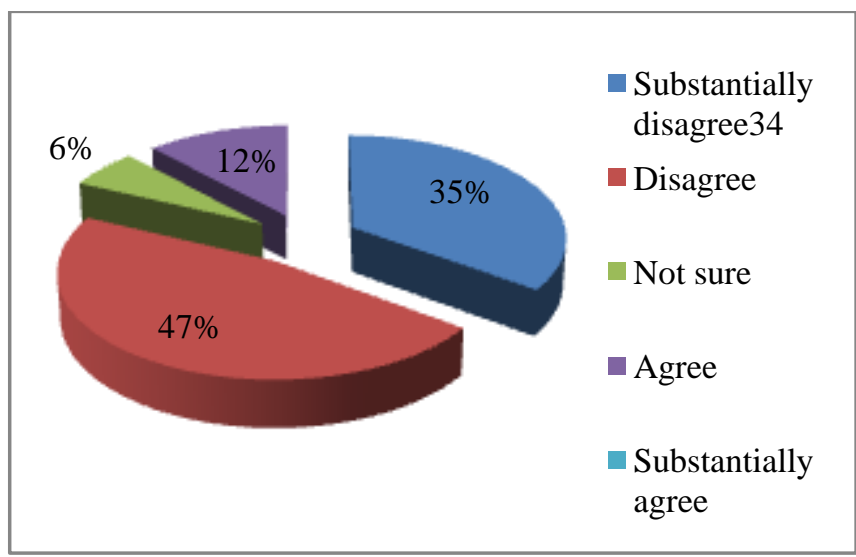

Figure 5: Percentages for "commitment between project parties".

\subsection{Unqualified and contractor experience}

According to the result collected from the survey, $68 \%$ of the total questionnaires agreed that this is the main problem in the construction field. While $26 \%$ for the respondent are "substantially agree" and only $6 \%$ of the respondents are not sure fig.6. The average index value 1.79 and standard deviation is 0.76 Table 2 . It can be noted that the problem of unqualified and experience contractor it's the main problem faced project consultant implementation in Saudi Arabia construction industry.

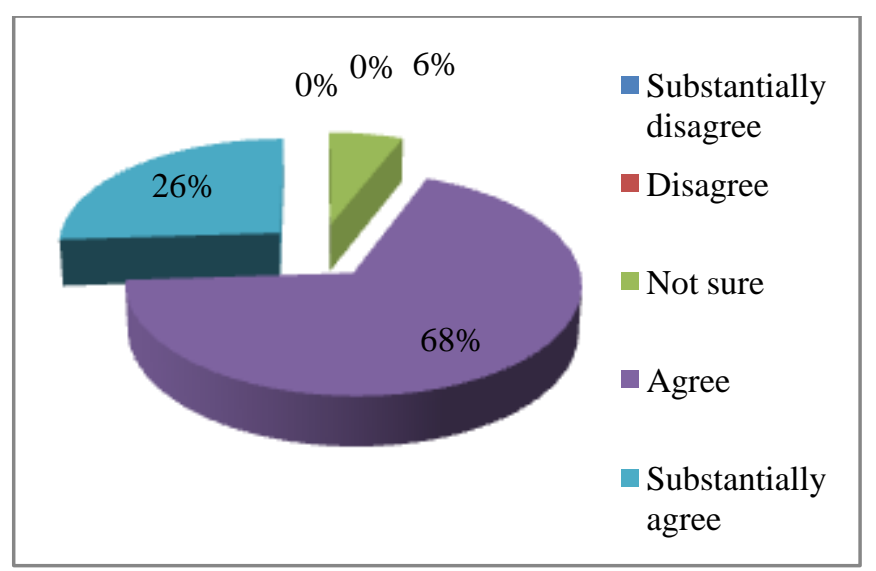

Figure 6: Percentages for "unqualified and experience contractor".

\subsection{Shortage of Manpower}

Fifty percent of the respondents disagree with the shortage of manpower in Saudi construction industry is problem, while $44 \%$ of the respondents "substantially disagree" in their decision, and $6 \%$ for the respondent are "not sure". Fig7. The average index value and standard deviation are 4.380 .65 respectively table 2 . From results it can be noted that the problem of shortage of man power is not a problem faced the project consultant implementation in Saudi Arabia construction industry. 


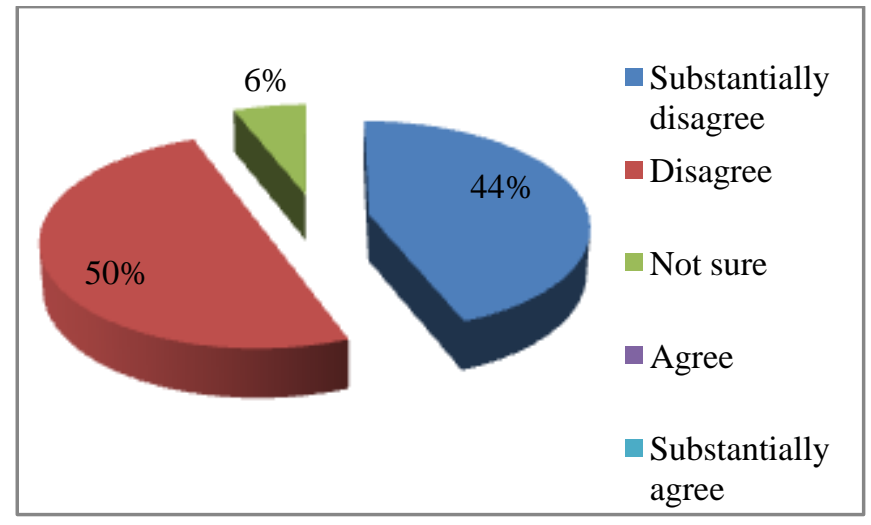

Figure 7: Percentages for "shortage of manpower".

\section{DISCUSSION}

Problems facing construction project consultant implementation in Saudi Arabia are unclear client statement, Lake of ability to manage the schedule, Problem of many projects in hand, poor coordination between project parties, lack of commitment between the parties, unqualified and contractor experience. The relative importance of these factors to construction projects consultant implementation was studied from point of view of expertise working in construction field in Saudi Arabia. The expertise in construction field in Saudi Arabia gives many reasons for their opinions for different problems faced construction projects. Construction experts considered that, unclear client statement, lake of ability to manage the schedule, Lack of commitment between the parties and Shortage of manpower are not problems facing construction projects consultant. Their reasons for that are the role of project consultant in project planning and owner requirements, qualified people in construction sector, existence project administration framework and labor office can supplement the required labor for the project respectively. This is may agree with [9] who carried out same study. Whereas they considered that problem of many projects in hand and problem of poor coordination between project parties are real problem facing project implementation owing to problems usually happened from the owner and existence of subcontractors respectively. However, construction expertise's considered unqualified and contractor experience are the main problem facing construction project due to project consultant does not choose the project contractor. This result agreed with the research carried out for Sudan by [10] as he concluded that the major problem faced consultation sector in Sudan is unqualified contractors.

\section{CONCLUSION}

The purpose of this study is to determine and evaluate the problems in implementing the project consultant in Saudi construction industry and to serve as a guide to the client who may wish to engage with project consultant services. From the average index estimated based on survey carried out it can be concluded that the problems faced project consultant implementation in Saudi Arabia construction industry mainly are unqualified and experience contractor, many projects and Poor coordination between project parties. However, unclear need statement by client, lake of organize, schedule workloads, Lack of commitment between the parties, and Shortage of manpower does not consider as problems faced implementing the project consultant in Saudi Arabia construction industry

\section{ACKNOWLEDGEMENT}

The authors would like to express their gratitude to $\mathrm{Mr}$. Abdelrhman Khalid Ali at the "Sudan Academy of Aviation Sciences and Technology", for his kind assistance.

\section{REFERENCE}

[1]. Cordsman A.H., (2000). "Saudi Arabia enters the 21st century V: economic, demographic and social challenges". Working Paper 2000, centre for strategic and international studies, Washington, DC.

[2]. Statistical Year Books, "Department of statistics ministry of finance and national economy", 2000, Riyadh, Saudi Arabia.

[3]. Sadi A. Assaf, Sadiq Al-Hejji., 24 (2006). "Causes of delay in large construction projects". International journal of project management 349-357.

[4]. Sweis G, Abu-Hammad A, and Shboul A., 26 (2007). "Delays in construction projects: the case of Jordan", international journal of project management, 665-674.

[5]. Mohamed A.M, Abdelraman.M, and Smaui.H., (2016). "Factors of project consultant selection in Saudi Arabia". International journal of research in engineering and technology, 05 (2016) 48-50.

[6]. Harold, Kerzner., (2004). "Advanced project management, best practices on implementation." 2nd edition, New Jersey, John Wiley \& Sons, Inc.

[7]. Hussien H.M., (2011). "Personnel job satisfaction and job performance in Sudan", master thesis, Universiti Teknologi Malaysia.

[8]. Abd. Majid M. Z. dan McCaffer R., (1997). "Discussion of work performance of maintenance contractors in Saudi Arabia”. Journal of management in engineering ASCE, Vol. 13, No. 5, Pg. 91.

[9]. Ismail D., (2005). "Services provided by project management consultant in Malaysian construction industry", master thesis, Universiti Teknologi Malaysia.

[10].Mohamed A.M., (2011). "Project management consultant in Sudanese construction industry", master thesis, Universiti Teknologi Malaysia. 